\title{
MICRO TRANSACTION DALAM ONLINE GAME: APAKAH MEMICU PERILAKU BELANJA ONLINE YANG BERMASALAH?
}

\author{
Garvin $^{1}$, Jennifer Claudia ${ }^{2}$, Irene Evita ${ }^{3}$ \\ ${ }^{123}$ Program Studi Psikologi, Universitas Bunda Mulia \\ garvin.goei@gmail.com
}

\begin{abstract}
In this study, the researcher examined one of the negative possible outcomes from micro transaction in online game, namely problematic online shopping behavior. Micro transaction is a feature in online game that allowed the user to have more ability and items, so it makes the user easier to play the game. The research included 474 research participants $(55.6 \%$ female $)$ of 14-18 years old adolescence in Jakarta. Then the participants were asked to fill the Compulsive Online Shopping Scale or COSS $(\alpha=0.926)$ and mentioned whether they have used the micro transaction or not in online game. The Mann-Whitney test result showed that there was no difference in compulsive online shopping in micro transaction user and non-micro transaction user in online game $(\mathrm{p}=0.715>0.05)$. This is because the adolescences just used the micro transaction occasionally, and factors that caused online compulsive buying in adolescence are peer reinforcement and modeling from parents. While in online game, the satisfaction gained were internal; not external as gained from peers and parents. Researcher suggested that parents keep monitoring adolescence in playing online game. And for the next research, some control variables can be involved such as the frequency of using micro transactions in a month and the genre of online games played.
\end{abstract}

Keywords: adolescence, compulsive online shopping, micro transaction, online game

\begin{abstract}
ABSTRAK
Pada penelitian ini, peneliti bermaksud untuk meneliti salah satu dampak dari online game yang timbul akibat adanya transaksi mikro, yakni perilaku belanja online yang bermasalah. Transaksi mikro merupakan fitur di dalam online game untuk mendapatkan kemampuan dan barang lebih sehingga memudahkan mereka dalam bermain, dan fitur tersebut diperoleh dengan cara membeli menggunakan uang di dunia nyata. Peneliti melibatkan 474 partisipan (55,6\% perempuan) remaja yang berusia antara 14 - 18 tahun. Partisipan kemudian diminta untuk mengisi kuesioner yang berisi Compulsive Online Shopping Scale atau COSS $(\alpha=$ 0,926) dan menyebutkan apakah mereka menggunakan transaksi mikro atau tidak dalam bermain online game. Hasil uji Mann-Whitney menunjukkan bahwa tidak terdapat perbedaan perilaku belanja kompulsif online pada kelompok pengguna transaksi mikro dan kelompok bukan pengguna transaksi mikro $(\mathrm{p}=0,715>0,05)$. Hal ini karena remaja hanya menggunakan transaksi mikro sesekali, dan faktor yang menyebabkan remaja terjebak dalam perilaku belanja kompulsif adalah penguatan dari sebaya dan mencontoh dari orangtua. Sedangkan dalam bermain online game, kepuasan yang diperoleh dalam menggunakan transaksi mikro diperoleh secara internal, bukan eksternal seperti dari sebaya atau orangtua. Peneliti menyarankan agar orangtua tetap memantau remaja dalam bermain online game. Dan dalam penelitian selanjutnya, beberapa variabel kontrol bisa dilibatkan seperti frekuensi mengunakan transaksi mikro dalam sebulan dan genre dari online game yang dimainkan.
\end{abstract}

Kata kunci: belanja kompulsif online, remaja, online game, transaksi mikro 


\section{PENDAHULUAN}

Bermain online game merupakan hal yang menyenangkan bagi remaja. Diketahui bahwa pada tahun 2012-2013 saja, 80\% pengguna online game di dunia adalah remaja dengan usia 15-19 tahun (Google Analytic dalam Christianti, Nanik, \& Setiono, 2016), dan angka tersebut masih bisa bertambah hingga hari ini. Memang, bermain online game sudah menjadi salah satu aktivitas yang paling sering dilakukan oleh remaja di waktu luang (David-Ferdon \& Hertz, 2007), sehingga remaja menjadi populasi pemain online game terbesar di dunia.

Ada beberapa alasan yang membuat remaja gandrung memainkan online game. Penelitian yang dilakukan oleh Souza dan Freitas (2017) menemukan bahwa tantangan, rasa senang, fantasi, dan interaksi sosial memicu remaja untuk bermain online game. Adapun pada penelitian di Indonesia, beberapa alasan remaja bermain online game adalah sebagai sarana hiburan (Christianti et al., 2016), upaya mengatasi tekanan dari tuntutan prestasi (Christianti et al., 2016). Hal ini tidaklah mengherankan, sebab remaja memang berada pada tahap perkembangan di mana mereka sedang mengalami individuasi, yakni berusaha untuk memiliki otonomi dan identitas pribadi (Papalia dan Feldman, 2012), serta memiliki tugas perkembangan untuk menjadi individu yang unik dan memiliki peran yang berharga dalam lingkungan, yang disebut sebagai identitas (Erikson dalam Papalia dan Feldman, 2012). Dalam online game, remaja dapat memilih avatar mereka sendiri, yang mencakup penampilan fisik, kepribadian, bahkan peran mereka di dalam dunia maya tersebut. Kemampuan-kemampuan tersebut menimbulkan rasa pemenuhan diri pada remaja dan membuat remaja menggemari online game. Hal ini dipertegas kembali oleh Yee (2006) yang menemukan bahwa terdapat tiga komponen yang memotivasi seseorang untuk bermain online game, yakni (1) prestasi, (2) sosial, dan (3) immersion atau pembenaman diri. Dalam online game, remaja bisa memiliki peran sosial yang mereka inginkan dan menjadi pahlawan dalam dunia maya. 
Kegandrungan remaja dalam bermain online game memberikan keuntungan bagi pelaku industri. Pasar online game dan electronic game melebihi pendapatan dari industri film dan bermain online game menjadi aktivitas waktu luang yang paling sering dilakukan di dunia (Baumgarten dalam Souza dan Freitas, 2017). Hal ini diperkuat lagi oleh kehadiran ponsel pintar atau smartphone yang memberikan peningkatan signifikan dalam penggunaan online game (Wei \& Lu, 2014).

Meski menguntungkan bagi pasar, namun bermain online game dianggap kurang menguntungkan bagi remaja. Seringkali remaja bermain online game secara berlebihan sehingga menimbulkan berbagai permasalahan baik secara psikologis, fisik, akademik, maupun sosial. Bermain online game secara berlebihan diketahui dapat menurunkan kepuasan hidup dan menyebabkan kecemasan (Mentzoni et al., 2011), indeks prestasi yang menurun (Jackson, von Eye, Fitzgerald, Witt, \& Zhao; 2011). Bahkan bermain online game secara berlebihan dapat memicu berbagai gangguan kesehatan pada remaja, seperti gangguan muscoskeletal dan berbagai gangguan psikosomatis (Hellstrom, Nilsson, Leppert, \& Aslund; 2015). Berbagai penelitian juga menunjukkan bahwa bermain online game secara berlebihan dapat memicu gejala depresi (Hellstrom et al., 2015). Di Indonesia, berbagai riset mengenai dampak-dampak negatif dalam bermain online game pun dilakukan. Secara akademik, intensitas bermain online game tinggi dapat memicu perilaku prokrastinasi akademik pada remaja (Kurniawan, 2017). Bermain lebih dari lima jam per hari dapat meningkatkan berbagai risiko kesehatan pada remaja (Griffiths, 2005).

Meskipun penelitian dampak-dampak bermain online game secara psikologis, sosial, maupun fisik sudah sering dilakukan, namun penelitian dampak online game terhadap perilaku konsumen remaja masih belum banyak dilakukan, terutama di Indonesia. Perkembangan teknologi membuat individu dapat membelanjakan uang mereka di dunia nyata untuk bendabenda yang tersedia secara virtual, seperti aksesoris atau peralatan-peralatan khusus di dalam 
dunia maya (Lehdonvirta, Wilska, dan Johnson; 2009), di mana fenomena ini dikenal sebagai konsumsi virtual atau virtual consumption, namun beberapa menyebutnya sebagai microtransaction. Adapun perilaku konsumen secara berlebihan atau konsumerisme di dalam dunia maya disebut sebagai konsumerisme virtual atau virtual consumerism. Perilaku konsumtif di dunia maya pada remaja dapat terjadi ketika remaja menggunakan uangnya secara berlebihan untuk membeli berbagai barang-barang virtual di dalam online game. Misalnya, remaja dapat membeli aksesoris, peralatan bertempur, maupun berbagai macam upgrade bagi avatarnya dalam dunia maya dengan menggunakan uang asli. Hal ini membuat remaja menghamburhamburkan uangnya di dunia nyata untuk membeli uang di dunia maya, yang akhirnya membentuk perilaku konsumtif. Peneliti sempat melakukan wawancara pra-penelitian untuk sedikit memahami perilaku membeli secara virtual pada remaja. Adapun remaja yang peneliti wawancarai mengaku bahwa melakukan transaksi di dunia maya tersebut dapat membantu kemajuan mereka dalam bermain game dan membuat avatar mereka tampil semakin menarik, sehingga mereka mendapatkan pengakuan dari teman-teman sebayanya yang ikut bermain online game dan menimbulkan rasa bangga (Komunikasi Personal, 2018). Tentu saja, hal tersebut sangat penting bagi remaja, sebab remaja membutuhkan pengakuan dalam rangka individuasi dan mereka mendapatkan pengakuan tersebut dari dunia maya.

Dalam behaviorisme, dikenal sebuah prinsip dasar yang disebut sebagai law of effect atau hukum efek. Hukum ini dicetuskan pertama kali oleh Edward Lee Thorndike (dalam Feist \& Feist, 2017) dan berbunyi bahwa seseorang akan cenderung mengulangi perilaku yang disertai dengan konsekuensi menyenangkan. Prinsip dasar ini kemudian dikembangkan lagi menjadi operant conditioning yang dicetuskan oleh B.F. Skinner dan menjadi dasar dalam teknik modifikasi perilaku manusia. Adanya kepuasan dan kesenangan yang remaja peroleh ketika melakukan micro-transaction dapat membuat remaja ingin mengulanginya lagi, dan ketika remaja mulai menghabiskan uangnya secara berlebihan untuk melakukan micro- 
transaction, peneliti mengkhawatirkan akan timbul konsumerisme pada remaja. Tentu saja, konsumerisme bukanlah hal yang positif bagi remaja. Oleh sebab itu, peneliti kemudian bermaksud untuk melakukan penelitian mengenai dampak bermain online game terhadap perilaku konsumtif pada remaja. Adapun tujuannya agar peneliti dapat mengidentifikasi sedini mungkin kemungkinan adanya dampak perilaku konsumtif pada remaja yang bermain online game dan melakukan micro-transaction, sehingga ke depannya dapat dilakukan tindakan pencegahan maupun penyelesaian.

Online game merupakan permainan elektronik yang dilakukan dengan menggunakan jaringan internet sehingga pemainnya bisa berkomunikasi satu sama lain. Adapun online game sudah menjadi salah satu aktivitas yang paling sering dilakukan oleh remaja di waktu luang (David-Ferdon \& Hertz, 2007). Beberapa alasan remaja bermain online game adalah sebagai sarana hiburan dan upaya mengatasi tekanan dari tuntutan prestasi (Christianti et al., 2016). Bermain online game secara berlebihan dapat menimbulkan masalah seperti menurunkan kepuasan hidup (Mentzoni et al., 2011), penurunan indeks prestasi (Jackson et al., 2011), gangguan kesehatan fisik (Hellstrom et al., 2015), prokrastinasi akademik (Kurniawan, 2017), hingga memicu gejala depresi (Hellstrom et al., 2015).

Micro-transaction merupakan transaksi keuangan kecil yang dilakukan secara online. Sejak berkembangnya era internet, micro-transaction menjadi sering dilakukan, terutama dalam online game. Bahkan, menurut EA, salah satu pengembang online game di dunia, seluruh video game akan menggunakan micro-transaction pada 5 hingga 10 tahun ke depan ("Microtransactions will be in every game", 2012). Hal ini berarti, kajian tentang microtransaction perlu diperhatikan. Penelitian mengenai micro-transaction dalam online game masih belum banyak dilakukan, namun penelitian terakhir mengenai micro-transaction dilakukan dalam konteks permainan kasino. Penelitian yang dilakukan oleh Kim, 
Hollingshead, dan Wohl (2016) menemukan bahwa pemain kasino yang melakukan microtransaction akan cenderung lebih impulsif dan lebih memiliki masalah perjudian yang parah.

Compulsive shopping atau perilaku belanja kompulsif disebut juga sebagai shopaholism. Andreassen (2014) mendefinisikan belanja kompulsif sebagai perasaan terlalu khawatir tentang belanja, didorong oleh motivasi belanja yang tidak terkendali, dan untuk menginvestasikan begitu banyak waktu dan upaya dalam berbelanja sehingga merusak area kehidupan penting lainnya. Munculnya internet dan berkembangnya e-commerce menyebabkan fenomena baru, yaitu belanja kompulsif secara online atau compulsive online shopping (Manchiraju, Sadachar, \& Ridgway; 2016). Andreassen et al. (2015) menyebutkan bahwa terdapat tujuh kriteria belanja kompulsif online, yakni (1) salience, (2) mood modification, (3) tolerance, (4) withdrawal, (5) conflict, (6) relapse, dan (7) problems.

\section{METODE PENELITIAN}

Penelitian ini merupakan penelitian kuantitatif non-eksperimental. Penelitian ini melibatkan 475 partisipan (55,6\% perempuan) remaja yang berusia antara 14 sampai dengan 18 tahun. Seluruh partisipan berdomisili di Jabodetabek dan peneliti tidak membatasi partisipan berdasarkan agama dan suku bangsa.

Tabel 1. Gambaran Partisipan Penelitian berdasarkan Usia

\begin{tabular}{|c|c|c|}
\hline Usia & Frekuensi & Persentase \\
\hline 14 tahun & 1 orang & $0,2 \%$ \\
\hline 15 tahun & 141 orang & $29,7 \%$ \\
\hline 16 tahun & 269 orang & $56,6 \%$ \\
\hline 17 tahun & 60 orang & $12,6 \%$ \\
\hline 18 tahun & 4 orang & $0,8 \%$ \\
\hline Total & 475 orang & $100 \%$ \\
\hline
\end{tabular}

Partisipan penelitian kemudian diminta untuk mengisi kuesioner penelitian yang terdiri dari data pribadi dan Compulsive Online Shopping Scale. 
Instrumen yang digunakan dalam penelitian ini adalah kuesioner, yang berisi Compulsive Online Shopping Scale (COSS). COSS disusun oleh Manchiraju, Sadachar, dan Ridgway (2006); terdiri dari 28 butir yang mengukur perilaku belanja kompulsif secara online. COSS terdiri dari 7 aspek, yakni: (1) salience, (2) mood modification, (3) conflict, (4) tolerance, (5) relapse, (6) withdrawal, dan (7) problems. Skala ini diterjemahkan ke dalam Bahasa Indonesia dan diujicobakan, menghasilkan reliabilitas yang memuaskan $(\alpha=0,926)$.

\section{HASIL}

Berdasarkan data yang diperoleh, peneliti melakukan uji beda pada skor COSS pada dua kelompok, yakni kelompok (1) yang tidak melakukan transaksi mikro pada online game, dan (2) yang melakukan transaksi mikro pada online game. Variabel bebas dari penelitian ini adalah transaksi mikro dan variabel terikat adalah perilaku online kompulsif. Sebelum melakukan uji beda, peneliti melakukan uji normalitas terlebih dahulu untuk mengetahui penyebaran data dari skor COSS pada partisipan.

Hasil uji normalitas pada COSS menunjukkan bahwa hasil sebaran data tidak membentuk kurva normal $(\mathrm{p}=0,000<0,05)$. Artinya, analisis data pada penelitian ini akan menggunakan statistik non-parametrik. Pada statistik non-parametrik, uji beda 2 variabel yang dilakukan akan menggunakan Mann-Whitney test.

Berdasarkan hasil Mann-Whitney test, diketahui bahwa tidak ada perbedaan perilaku belanja kompulsif online pada kelompok yang melakukan transaksi mikro maupun tidak ( $\mathrm{p}=$ 0,715 > 0,05). Peneliti kemudian melakukan uji Mann-Whitney kembali pada aspek-aspek dari belanja kompulsif online, yakni (1) salience, (2) mood modification, (3) conflict, (4) tolerance, (5) relapse, (6) withdrawal, dan (7) problems. Hasil pengujian juga menunjukkan bahwa tidak ada perbedaan pada satu aspek pun pada kelompok yang melakukan transaksi mikro maupun tidak. 
Tabel 2. Hasil uji beda pada aspek-aspek perilaku belanja kompulsif online

\begin{tabular}{|l|l|l|}
\hline Aspek & Signifikansi & \multicolumn{1}{c|}{ Simpulan } \\
\hline Salience & $\mathrm{p}=0,381$ & Tidak ada perbedaan yang signifikan \\
\hline Mood modification & $\mathrm{p}=0,892$ & Tidak ada perbedaan yang signifikan \\
\hline Conflict & $\mathrm{p}=0,582$ & Tidak ada perbedaan yang signifikan \\
\hline Tolerance & $\mathrm{p}=0,451$ & Tidak ada perbedaan yang signifikan \\
\hline Relapse & $\mathrm{p}=0,842$ & Tidak ada perbedaan yang signifikan \\
\hline Problems & $\mathrm{p}=0,531$ & Tidak ada perbedaan yang signifikan \\
\hline
\end{tabular}

Berdasarkan hasil di atas, maka diketahui bahwa tidak ada perbedaan pada semua aspek perilaku belanja kompulsif online berdasarkan pernah atau tidaknya seseorang melakukan transaksi mikro pada bermain online game.

Meskipun transaksi mikro memberikan kemudahan dalam bermain online game, namun tidak terdapat perbedaan perilaku belanja kompulsif online pada pelaku transaksi mikro dan tidak. Roberts, Manolis, dan Tanner (2006) menyatakan bahwa ada dua komponen yang berperan terhadap perilaku belanja kompulsif pada remaja, yakni orangtua dan sebaya. Meskipun transaksi mikro memberikan kemudahan, tetapi remaja tidak terpengaruh untuk menjadi kompulsif karena tidak ada penguatan dari orangtua dan sebaya. Kepuasan yang diperoleh dari melakukan transaksi mikro dalam bermain online game lebih dirasakan secara internal (lebih mudah naik level atau merasakan keseruan lebih dalam bermain). Kepuasan yang bersifat internal tersebut tidak membuat remaja terjebak dalam perilaku belanja kompulsif online, sebab perilaku belanja kompulsif remaja lebih dipengaruhi oleh faktor eksternal.

Agar mendapatkan data yang lebih mendalam, peneliti mencoba mewawancarai 3 partisipan yang melakukan transaksi mikro dalam bermain online game. Baik ketiganya 
menjawab bahwa mereka hanya melakukan transaksi mikro sesekali saja, dalam artian mereka tidak rutin melakukan transaksi mikro dan hanya melakukannya bila diperlukan saja.

Peneliti merasa bahwa masih banyak hal yang seharusnya digali untuk memeroleh pembahasan yang lebih mendalam. Hal ini akan dibahas pada saran untuk penelitian selanjutnya.

\section{KESIMPULAN DAN SARAN}

Berdasarkan data-data yang sudah peneliti kaji, diperoleh hasil bahwa tidak terdapat perbedaan perilaku belanja kompulsif online yang signifikan antara pengguna transaksi mikro dan bukan pengguna transaksi mikro pada pemain online game. Melalui hasil tersebut, disimpulkan bahwa transaksi mikro tidak menyebabkan perilaku belanja kompulsif online pada remaja. Artinya, transaksi mikro pada online game tidak menimbulkan perilaku berbelanja yang bermasalah. Hal ini disebabkan karena kepuasan yang diperoleh dari transaksi mikro bersifat internal saja, sedangkan perilaku belanja kompulsif remaja lebih dipengaruhi oleh faktor eksternal. Oleh karena itu, remaja hanya sesekali saja melakukan transaksi mikro saat bermain online game.

Penelitian ini memberikan saran baik secara praktis dan teoretis. Secara praktis, penelitian ini menunjukkan bahwa transaksi mikro pada online game tidak menimbulkan perilaku belanja kompulsif online pada remaja. Artinya, orangtua tidak perlu terlalu khawatir dengan aktivitas remaja dalam bermain online game, selama remaja bermain dalam porsi yang seharusnya. Namun bukan berarti orangtua membiarkan saja remaja bermain online game, orangtua masih harus memerhatikan dan memantau agar remaja tidak terjebak dalam perilaku bermasalah yang ditimbulkan oleh online game.

Secara teoretis, peneliti merasa bahwa masih banyak hal yang perlu digali untuk mendapatkan pembahasan yang lebih dalam. Salah satunya, peneliti merasa bahwa data 
frekuensi melakukan transaksi mikro dalam sebulan seharusnya diambil sebagai data kontrol.

Selain itu, data genre dalam online game juga perlu dikontrol. Beberapa genre seperti MMORPG mungkin lebih membutuhkan transaksi mikro daripada genre lainnya. Peneliti selanjutnya yang tertarik untuk meneliti dengan topik ini disarankan agar mempertimbangkan variabel-variabel untuk penelitian selanjutnya.

\section{DAFTAR PUSTAKA}

Andreassen, C.S. (2014). Shopping addiction: an overview. Journal of Norwegian Psychological Association, 51, 194-209.

Andreassen, C.S., Griffiths, M.D., Pallesen, S., Bilder, R.M., Torsheim, T., \& Aboujaoude, E. (2015). The Bergen shopping addiction scale: reliability and validity of a brief screening test. Frontiers in Psychology, 6, doi: 10.3389/fpsyg.2015.01374.

Christianti, A., Nanik, \& Setiono, V. (2016). Studi deksriptif: psychological well-being pada remaja yang kecanduan bermain online game di Surabaya. Calyptra: Jurnal Ilmiah Mahasiswa Universitas Surabaya, 5(1), 1-12.

David-Ferdon, C., \& Hertz, M.F. (2007). Electronic media, violence, and adolescents: an emerging public health problem. Journal of Adolescent Health, 41(6), 1-5.

Griffiths, M. (2005). Video game addiction: does it exist? Dalam J. Raessens \& J.H. Goldstein, Handbook of Computer Game Studies. MA: MIT Press.

Hellstrom, C., Nilsson, K.W., Leppert, J., \& Aslund, C. (2015). Effects of adolescent online gaming time and motives on depressive, muscoskeletal, and psychosomatic symptoms. Upsala Journal of Medical Sciences, 120(4), 263-275.

Jackson, L.A., von Eye, A., Fitzgerald, H.E., Witt, E.A., \& Zhao, Y. (2011). Internet use, videogame playing and cell phone use as predictors of children's body mass index (BMI), body weight, academic performance, and social and overall self-esteem. Computers in Human Behavior, 27(1), 599-604.

Kurniawan, D.E. (2017). Pengaruh intensitas bermain online game terhadap perilaku prokrastinasi akademik pada mahasiswa bimbingan dan konseling Universitas PGRI Yogyakarta. Jurnal Konseling Gusjigang, 3(1), 97-103.

Lehdonvirta, V., Wilska, T., \& Johnson, M. (2009). Virtual consumerism: Case Habbo Hotel. Information, Communication, \& Society, 12(7), 1069-1079.

Manchiraju, S., Sadachar, A., \& Ridgway, J.L. (2016). The compulsive online shopping scale (COSS): Development and validation using panel data. International Journal of Mental Health and Addiction, 15(1), h.209-223.

Mentzoni, R.A., Brunborg, G.S., Molde, H., Skouveroe, K.J., Hetland, J., \& Pallesen, S. (2011). Problematic video game use: estimated prevalence and associations with mental and physical health. Cyberpsychology, Behavior, and Social Networking, 14(10), 591596.

"Microtransactions will be in every game, says EA exec". (2012, 22 Juni). Diakses pada 2018, 12 April, dari https://www.gamespot.com/articles/microtransactions-will-be-in-everygame-says-ea-exec/1100-6383445/

Kim, H.S., Hollingshead, S., Wohl, M.J.A. (2016). Who spends money to play for free? Identifying who makes micro-transactions on social casino games (and why). Journal of Gambling Studies, 33(2), 525-538. 
Papalia, D.E., \& Feldman, R.D. (2012). Experience human development $\left(12^{\text {th }}\right.$ ed.). NY: McGraw-Hill.

Souza, L.L.F., \& Freitas, A.A.F. (2017). Consumer behavior of electronic games' players: a study on the intentions to play and to pay. Revista de Administracao, 52, 419-430.

Wei, P.S., \& Lu, H.P. (2014). Why do people play mobile social games? An examination of network externalities and of uses and gratifications. Internet Research, 24(3), 313-331.

Yee, N. (2006). Motivations for play in online games. Cyberpsychology and Behavior, 9(6), 772-775. 